\title{
Microcalorimetric study of the growth of Streptococcus thermophilus in renneted milk
}

\author{
Irina Stulova ${ }^{1,2}{ }^{*}$, Natalja Kabanova $^{2}$, Tiina Kriščiunaite ${ }^{2}$, Kaarel Adamberg ${ }^{1,2}$, Tiiu-Maie Laht ${ }^{1}$ and \\ Raivo Vilu ${ }^{1,2}$
}

${ }^{1}$ Department of Chemistry, Tallinn University of Technology, Tallinn, Estonia

${ }^{2}$ Competence Centre of Food and Fermentation Technologies, Tallinn, Estonia

\section{Edited by:}

Michael Gänzle, Alberta Veterinary

Research Institute, Canada

Reviewed by:

Louis Coroller, Université de Brest,

France

Laurent Guillier, Agence Nationale de Sécurité Sanitaire de

I'Alimentation, de l'Environnement et du Travail, France

*Correspondence:

Irina Stulova, Department of Chemistry, Tallinn University of

Technology, Akadeemia Tee 15,

Tallinn 12618, Estonia

e-mail: irina.stulova@tftak.eu
The growth of Streptococcus thermophilus ST12 (ST12) in liquid milk, reconstituted from low-heat skim milk powder reconstituted skim milk (RSM) and in RSM with rennet addition ( $r-R S M)$ at $40^{\circ} \mathrm{C}$ was monitored by microcalorimetry. It was shown that the growth rate of bacteria decreased in renneted samples in comparison with liquid RSM starting from certain sizes of the colonies ("deviation moments"), which depended on the inoculation rates. The hydrolysis of lactose was delayed for about $1 \mathrm{~h}$ in the r-RSM in comparison with RSM but otherwise the metabolism of carbohydrates in the renneted and non-renneted milks was similar. The total free amino acids (TFAA) content by the end of fermentations was higher in r-RSM than in RSM presumably due to the enzymatic hydrolytic activity of rennet. The quantitatively dominating amino acids were remarkably different in the r-RSM and RSM indicating that the hydrolysis cascade of caseins and/or metabolism of amino acids by the bacteria functioned differently in the two cases. The data obtained showed potential of microcalorimetry to characterize quantitative differences of growth and metabolism of the bacteria in renneted and liquid samples of milk.

Keywords: Streptococcus thermophilus, growth and metabolism of the bacteria, milk, renneted milk, microcalorimetry

\section{INTRODUCTION}

Studies of growth of LAB in the liquid milk (Favrot and Maubois, 1994, 1996; Letort et al., 2002) and solid cheese are complicated because traditional microbiological methods are not well suited for the enumeration of bacteria in opaque and especially in solid media. Peculiarities of colonial growth of bacteria in solid transparent matrices (agar, gelatine) have been described, however, in several papers (Brocklehurst et al., 1995; McKay et al., 1997; Malakar et al., 2002; Wilson et al., 2002; Kabanova et al., 2009, 2012; Velliou et al., 2013). Studies of growth of LAB in solid coagulated milk samples are clearly less numerous (Favrot and Maubois, 1996; Floury et al., 2010, 2013; Jeanson et al., 2011). One of the reasons of the noted scarcity is the lack of suitable methods for the studies.

The most noticeable advantage of the calorimetric method in comparison with the other mostly invasive techniques is the possibility to follow the bacterial growth in opaque and/or solid environments like various food matrices monitoring the heat evolution without destroying or perturbing samples studied (Lobete et al., in press). The calorimetric technique was first used in dairy research in seventies for milk grading (Berridge et al., 1974) and growth studies of pure LAB cultures under limiting substrate conditions (Fujita et al., 1978). The interactions of Streptococcus thermophilus and Lactobacillus bulgaricus were studied in milk using calorimetry in 1979 (Monk, 1979). Riva et al. (1997) investigated shelf life of fresh milk using isothermal calorimetry for continuous monitoring of microbial growth. Gardea et al. (2002) compared heat evolution by bacteria with the results of traditional plate counts assessing microbiological quality of milk undergone different treatments. Wadsö and Galindo (2009) compared the thermal power-time profiles of the fermentation of milk at two incubation temperatures using two different buttermilk cultures. Kriščiunaite et al. (2011) applied microcalorimetry to study the influence of $\mathrm{H}_{2} \mathrm{O}_{2}$ on the growth of thermophilic starter bacteria in UHT milk.

A considerable methodical improvement in use of microcalorimetry was introduced in Kabanova et al. (2009) and Kabanova et al. (2012). Two major advancements introduced were as follows: (a) a method of serial dilution was developed, which means that inoculation rates of the bacteria in the samples were changed from $10^{0}$ to $10^{6} \mathrm{CFU} \mathrm{mL} \mathrm{mL}^{-1}$ with the precisely ten-fold increment increment. This allows to study the growth of the populations and colonies of different numbers of cells, and (b) a number of additional samples prepared in parallel with the microcalorimetric samples are incubated at the same temperature, and they are used for the measurements of sugars, organic and amino acids etc. The data obtained from the study of these parallel samples is used together with the microcalorimetric data. The approach was applied for the characterization of peculiarities of the growth of Streptococcus thermophilus ST12 in differently pretreated milk samples (Stulova et al., 2011), and in milk reconstituted from non-irradiated and irradiated at $10 \mathrm{kGy}$ milk powder (Stulova et al., 2013). 
The approach developed was used also in this paper. The specific aim of the present study was to investigate the growth of Streptococcus thermophilus ST12 in renneted reconstituted skim milk (RSM) (in milk gel) and compare the peculiarities of the growth with those in liquid milk samples.

\section{MATERIALS AND METHODS PREPARATION OF RECONSTITUTED SKIM MILK (RSM)}

Low heat skim milk powder (LHSMP) was obtained from Valio Ltd. (Helsinki, Finland). LHSMP was suspended in distilled water to yield a final concentration of $10 \%\left(\mathrm{w} \mathrm{v}^{-1}\right)$ milk solids, with addition of $\mathrm{CaCl}_{2}$ in final concentration of $10 \mathrm{mM}$. The samples with LHSMP were mixed thoroughly for $1 \mathrm{~h}$ at room temperature, heated at $90^{\circ} \mathrm{C}$ for $30 \mathrm{~min}$ and cooled to $30^{\circ} \mathrm{C}$ immediately before the experiments and used as liquid RSM samples.

\section{BACTERIAL CULTURES AND PREPARATION OF INOCULUM}

The strain of Streptococcus thermophilus ST12 (further St. thermophilus ST12) was kindly provided by Chr. Hansen (Hørsholm, Denmark). Deep-frozen cultures of St. thermophilus ST12 were thawed and pre-grown on M17 agar (LAB M, Lancashire, UK) for $24 \mathrm{~h}$ at $40^{\circ} \mathrm{C}$. One colony from a M17 agar plate was inoculated into $10 \mathrm{~mL}$ of RSM and left at $40^{\circ} \mathrm{C}$ until coagulation $(16 \mathrm{~h})$. One per cent of the culture was used for inoculation of the $10 \mathrm{~mL}$ of RSM samples, left until coagulation $(12 \mathrm{~h})$ and further used for inoculation of the microcalorimetry samples. The number of viable cells in the inocula was determined by plating on M17 agar followed by incubation for $72 \mathrm{~h}$ at $40^{\circ} \mathrm{C}$ to be $(1.15 \pm 0.19) \times$ $10^{9} \mathrm{CFU} \mathrm{mL}^{-1}$.

\section{PREPARATION OF SAMPLES FOR GROWTH EXPERIMENTS}

RSM as growth media were prepared in $50 \mathrm{~mL}$ Erlenmeyer flasks. Milk samples were inoculated with $1 \%\left(\mathrm{v} \mathrm{v}^{-1}\right)$ of inoculum and stirred thoroughly. The concentrations of inocula in milk samples for microcalorimetry were varied from $10^{1}$ to $10^{6} \mathrm{CFU} \mathrm{mL} \mathrm{m}^{-1}$ with the 10-fold increment. Milk gels were prepared by addition of $100 \mu \mathrm{l}$ of a $10 \mathrm{~g} \mathrm{~L}^{-1}$ chymosin (CHY-MAX Powder Extra, Hørsholm, Denmark) aqueous solution to $10 \mathrm{~mL}$ of RSM. The enzyme (chymosin) was added immediately after the inoculation. Milk samples for the microcalorimetric experiments, $2 \mathrm{~mL}$ samples of RSM and r-RSM were transferred into the autoclaved microcalorimetric ampoules, inserted into microcalorimeter and maintained at $40^{\circ} \mathrm{C}$. Monitoring of the growth of microorganisms was started in microcalorimeter about $1 \mathrm{~h}$ after the inoculation, after the temperature of the samples was in perfect equilibrium with the set temperature of the thermostat $\left(40^{\circ} \mathrm{C}\right)$. Taking into account that the coagulation of the liquid milk samples was over in $40 \mathrm{~min}$ after the inoculation, the growth of the bacteria in case of the r-RSM samples was studied in practice in solid gel matrices from the beginning of the microcalorimetric monitoring.

The remaining after the preparing of the microcalorimetric samples inoculated and renneted milks were divided into $1 \mathrm{~mL}$ aliquots and incubated at $40^{\circ} \mathrm{C}$ in parallel with the samples in microcalorimeter and used for the determination of $\mathrm{pH}$ and the concentrations of carbohydrates, lactic acid and amino acids at appropriate time points, determined based on the peculiarities of power-time curves.

\section{MICROCALORIMETRY}

A 24 channel isothermal batch microcalorimeter TAM III Thermal Activity Monitor (TA Instruments, New Castle, DE, USA) was used for the monitoring of the growth of thermophilic starter St. thermophilus ST12. Data acquisition and analysis was carried out using TAM Assistant Program (v 0.9.1012.40, SciTech Software AB, Thermometric $\mathrm{AB}$ ).

\section{Analysis of calorimetric power-time curves and calculation of growth characteristics}

The power-time curves, the output of microcalorimeter describe the heat evolution during the processes studied. A calorimetric

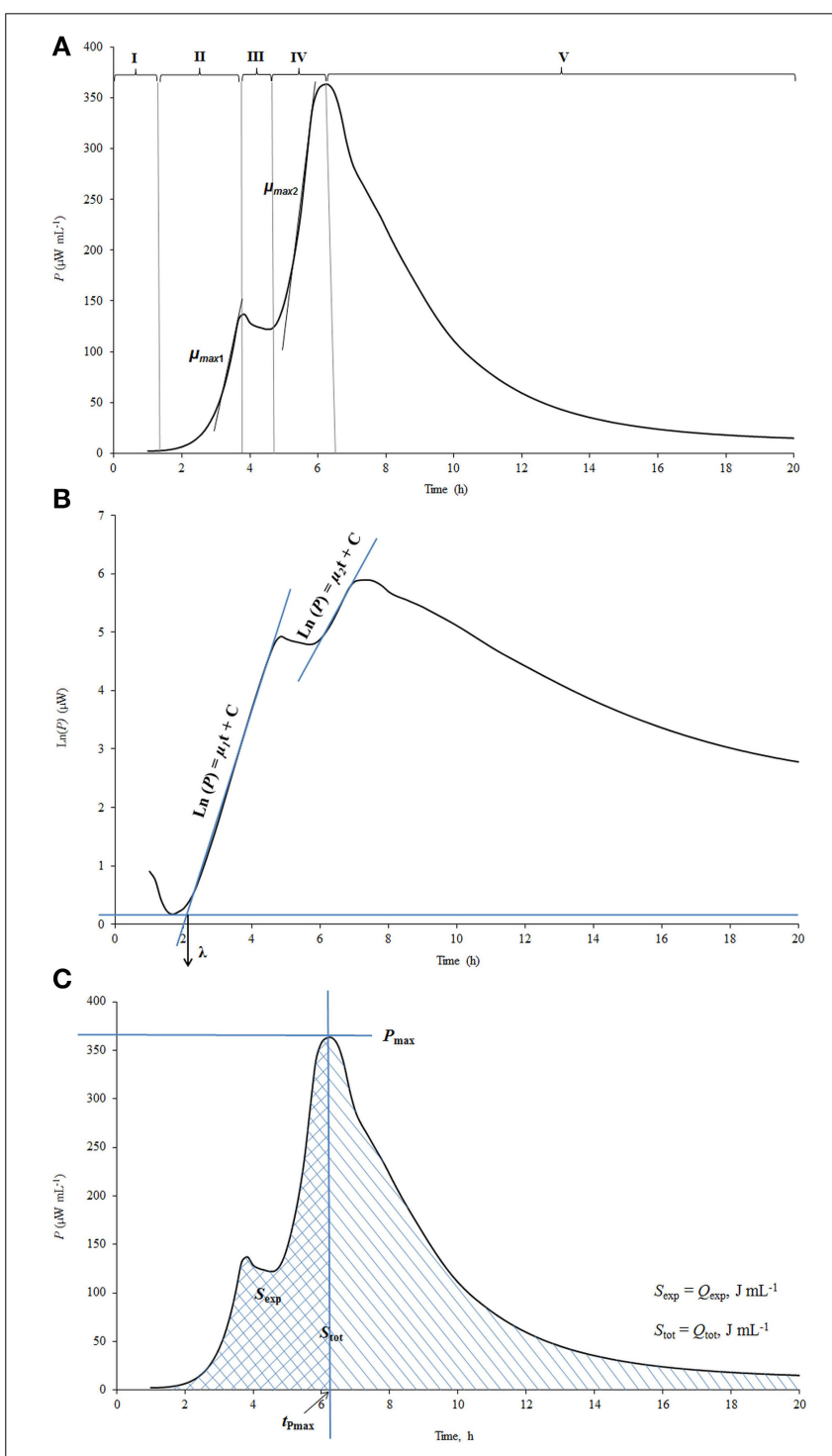

FIGURE 1 | The explanation of the processing of calorimetric power-time curves. (A) The division of calorimetric power-time curves into five phases; (B) Determination of the maximal calorimetric growth rates during the first $\left(\mu_{\max 1}, \mathrm{Wh}^{-1}\right)$ and the second exponential phase $\left(\mu_{\max 2 \text {, }}\right.$ $\left.\mathrm{Wh}^{-1}\right)$, and the duration of the lag-phase $(\lambda, \mathrm{h})$; (C) Determination of the heat evolution during combined exponential phases $\left(Q_{\text {exp }}\right)$, and during the growth of the cultures $\left(Q_{\text {tot }}\right)$. 
power-time curve of the growth of St. thermophilus ST12 in milk measured by us (Stulova et al., 2013) was divided into five different growth phases as shown in Figure 1A.

The pregrowth phase after the inoculation in the beginning of the graph is characterized as the lag-phase (I) during which bacterial cells adapt to the new environment. The length of the lag-phase was determined as shown on Figure 1B, where the power-time curve is presented in semilog scale. It is important to note that in measuring of the length of the lag-phase on the basis of calorimetric curves the sensitivity of the instrument TAM III $\left(7 \times 10^{-4} \mathrm{~J} / 0.5 \mu \mathrm{W}\right)$ as well as the time during which heat produced by the cells exceeds the level of sensitivity of the instrument should be taken into account (see Kabanova et al., $2009,2012)$. The second phase of the power-time curves following the lag-phase corresponds to the first exponential growth phase (II) during which the bacteria grow at the maximal calorimetric growth rate $\mu_{\max }$ possible in the experimental conditions studied. During the intermediate non-exponential growth phase (III) lactic acid bacteria presumably synthesize proteinases and metabolism of this bacteria switch from growth on free amino acids (FAA) present in milk to growth on amino acids and peptides released by the enzymes synthesized (Letort et al., 2002). The ends of the first as well as the second exponential phases (IV) of bacterial growth were defined by the corresponding peaks of the power-time curves. In case of analysis of certain metabolic characteristics of the bacteria during the growth (consumption patterns of amino acids etc.) the two exponential phases were considered as one-see below. After the second exponential growth phase the deceleration phase $(\mathrm{V})$ which combines the stationary phase of the growth together with the deceleration of the metabolism of lactic acid bacteria growing in milk was taking place.

Maximum specific growth rate $\left(\mu_{\max }\right)$, which could be considered also as maximal calorimetric growth rate during the first and second exponential growth phases was measured as shown in Figure 1B. Taking into account that during the exponential growth phase the relationship between biomass concentration

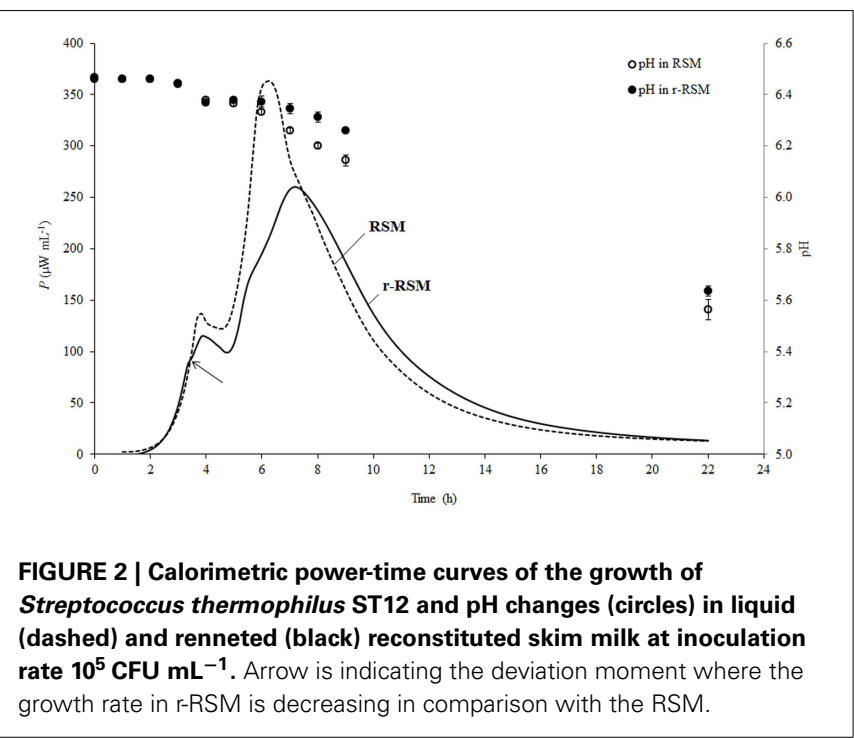

$(X)$ and specific growth rate $(\mu)$ may be described by the first order kinetics:

$$
\frac{d X}{d t}=\mu X
$$

and assuming that the rate of biomass formation $(\mathrm{d} X / \mathrm{d} t)$ was proportional to the rate of heat production $(\mathrm{dQ} / \mathrm{d} t)$, the maximum specific growth rate $\left(\mu_{\max }\right)$ was calculated from the power-time curves as a slope of $\ln \mathrm{d} Q / \mathrm{d} t$ over time $(t)$, as shown in Maskow and Babel (2003):

$$
\ln \frac{d Q}{d t_{t}}=\frac{d Q}{d t_{0}}+\mu_{\max } t
$$

The heat produced during the exponential growth phase $Q_{\exp }$ (area between the power-time curve and the vertical line that goes through the major peak of the power-time curve $\left(P_{\max }\right.$ value) and the baseline-see Figure $\mathbf{1 C}$ and the total heat produced during the whole process of growth $Q_{\text {tot }}$ (area between the power-time curve and baseline) were determined using the TAM Assistant program (v 0.9.1012.40, SciTech Software AB, Thermometric $\mathrm{AB}$, Järfälla, Sweden) and Microsoft Excel. The recording of the heat evolution was taking place with the frequency $1 \mathrm{~s}^{-1}$.

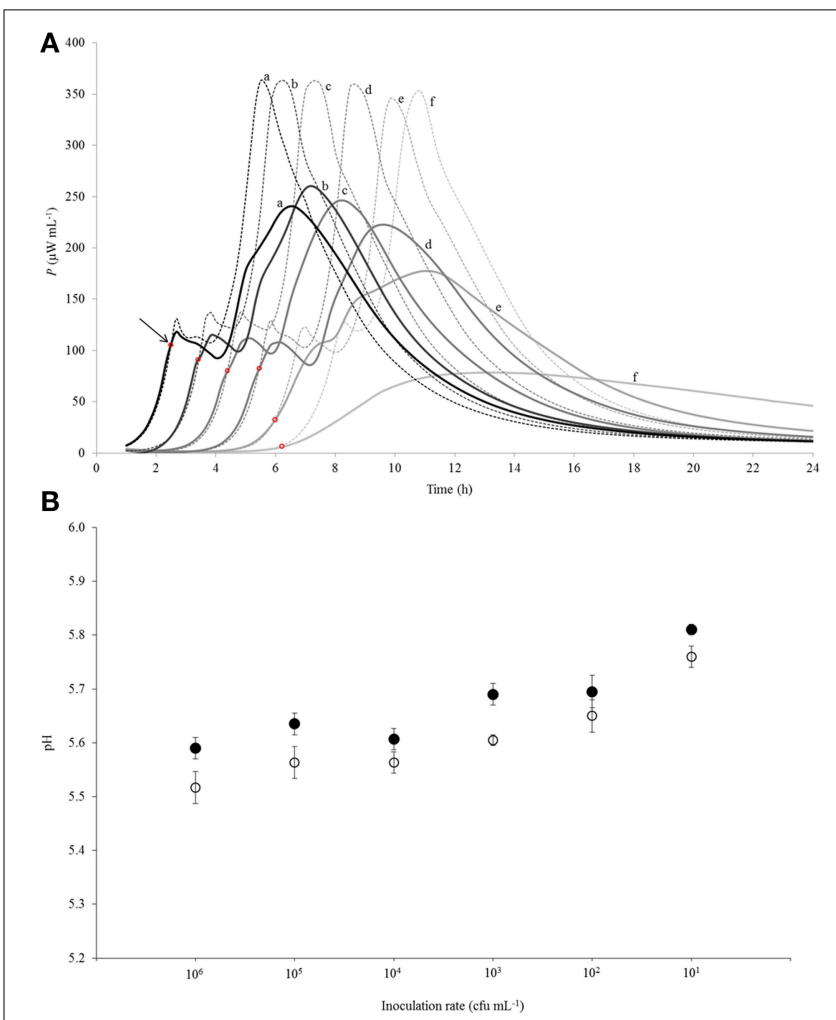

FIGURE 3 | (A) Calorimetric power-time curves describing growth of Streptococcus thermophilus ST12 in liquid (dashed line) and renneted (bold line) reconstituted skim milk at different inoculation rates (CFU $\mathrm{mL}^{-1}$ ): (a) $10^{6}$; (b) $10^{5}$; (c) $10^{4}$; (d) $10^{3}$; (e) $10^{2}$; (f) $10^{1}$. The arrow and the red circles mark the "deviation moments." (B) pH at the end of fermentation (at $22 \mathrm{~h}$ ) at all inoculation rates $\left(10^{6}-10^{1} \mathrm{CFU} \mathrm{mL} \mathrm{m}^{-1}\right)$ in RSM (white circles) and in $\mathrm{r}$-RSM (black circles). Initial $\mathrm{pH}=6.47$ was the same in the samples. 
The time-points were resampled at equidistant intervals of $15 \mathrm{~min}$.

The value $P_{\max }$ is characterizing the maximum aggregate rate of heat production (see Figure 1C). After reaching the maximum, the decrease of heat production rate starts. The time point where $P_{\max }$ is measured is a convenient time for the end of the exponential growth phase $(\mathrm{s})$.

The change of the number of viable cells over time was calculated using the equation (Stulova et al., 2013):

$$
N=\frac{\Delta Q}{Y Q}
$$

where $N\left(\mathrm{CFU} \mathrm{mL} \mathrm{mL}^{-1} \mathrm{~h}^{-1}\right)$ is the number of bacteria grown during the selected time interval, $\Delta Q\left(\mathrm{~J} \mathrm{~mL}^{-1} \mathrm{~h}^{-1}\right)$ is the heat produced during the same time interval, and $Y_{Q}\left(\mathrm{~J} \mathrm{CFU}^{-1}\right)$ is the experimentally determined heat yield coefficient $\left(Y_{Q}, \mathrm{~J}\right.$ $\left.\mathrm{CFU}^{-1}\right)$. Heat yield coefficient $\left(Y_{Q}, \mathrm{~J} \mathrm{CFU}^{-1}\right)$ was calculated on the basis of the results obtained from the experiments of ST12 growth in liquid RSM. The plate count was carried out at the end of exponential growth phase $\left(6.31^{*} 10^{8} \mathrm{CFU} \mathrm{mL} \mathrm{m}^{-1}\right)$ and heat amount produced was calculated from the power-time curves $(2.81 \mathrm{~J})$. The value of $Y_{Q}\left(\mathrm{~J} \mathrm{CFU}^{-1}\right)$ was determined to be $Y_{Q}=2.81 \mathrm{~J} / 6.31^{*} 10^{8} \mathrm{CFU} \mathrm{mL}^{-1}=4.45^{*} 10^{-9} \mathrm{~J} \mathrm{CFU}^{-1}$. Our earler experiments (unpublished data) showed that the $Y_{Q}$ value depended remarkably on the temperature of the growth but not on the media composition or inoculation rate. The $Y_{Q}$ value indicated was used for the description of growth in the liquid cultures (RSM) as well as in the case of solid-state growth (in r-RSM).

The numbers of bacteria at the end of exponential growth

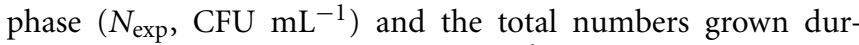
ing the whole process $\left(N_{\text {tot }}, \mathrm{CFU} \mathrm{mL} \mathrm{m}^{-1}\right)$, and also at "deviation moments" ( $\left.N^{*}, \mathrm{CFU} \mathrm{mL}^{-1}\right)$-see below, were calculated from heat evolution data $Q_{\exp }\left(\mathrm{J} \mathrm{mL}^{-1}\right)$ and $Q_{\text {tot }}\left(\mathrm{J} \mathrm{mL}^{-1}\right)$, and $Q^{*}$ $\left(\mathrm{J} \mathrm{mL}^{-1}\right)$ using the indicated above $Y_{Q}$ value (Kabanova et al., 2012).

The radii of average spherical model colonies $\left(R_{\text {col }}, \mu \mathrm{m}\right)$ were calculated from average volumes of colonies using Kepler's conjecture of packing of determined by heat measurements numbers of bacteria in colonies (Hsiang, 1993; Hales, 1994)—see a detailed discussion of the use of the conjecture in Kabanova et al. (2012).

Table 1 | Growth characteristics of Streptococcus thermophilus ST12 in RSM and r-RSM at $40^{\circ} \mathrm{C}^{\mathrm{a}}$.

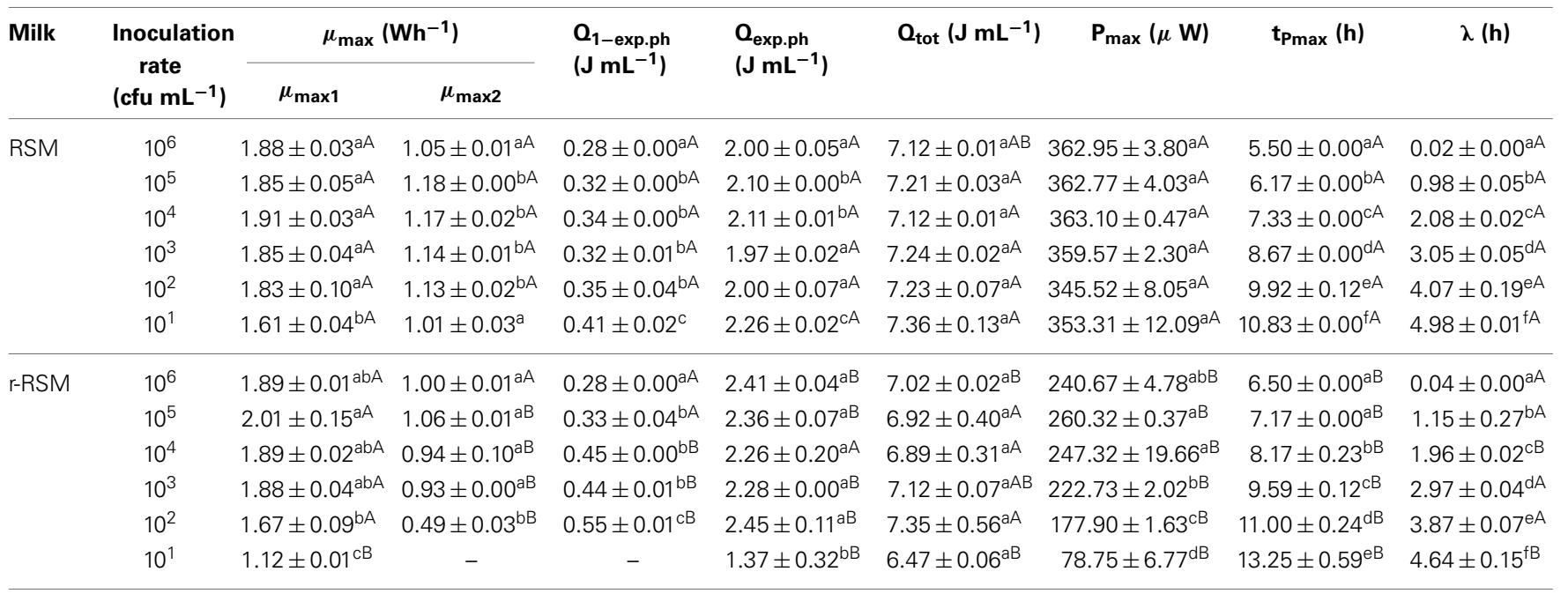

${ }^{a}$ Data are means $\pm S D$ of maximal calorimetric growth rate $\left(\mu_{\max }\right)$ in the first and second exponential growth phase, the heat evolved during the first and second exponential phase $\left(Q_{1 \text { stexp.ph }}\right.$ and $\left.Q_{\text {exp.ph }}\right)$, the total heat produced during the whole fermentation $\left(Q_{\text {tot }}\right)$, maximum heat flow $\left(P_{\text {max }}\right)$, the time of the maximum heat production rate ( $\left.t_{P \max }\right)$ and lag phase duration $(\lambda)$ obtained from microcalorimetric power-time curves.

Table 2 | The $t$-test analysis denoting the differences between liquid and renneted RSM samples.

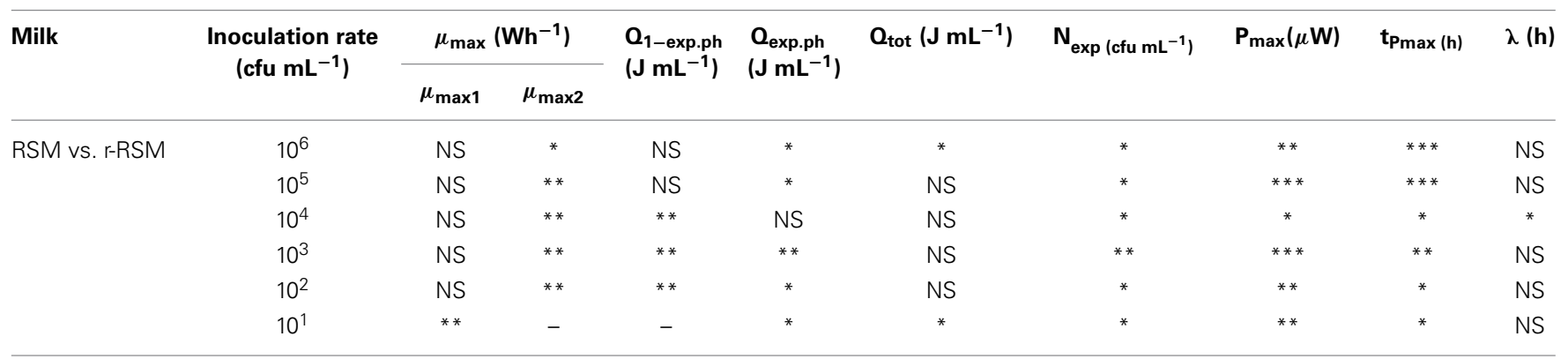

NS-not significant, ${ }^{*} P<0.05,{ }^{* *} P<0.01,{ }^{* *} P<0.001$. 


\section{ANALYTICAL METHODS}

Incubated in parallel to the microcalorimetric samples milk samples were mixed at chosen times 1:1 with isopropanol for sedimentation of proteins. The precipitate was removed by centrifugation at $14,000 \times \mathrm{g}$ for $10 \mathrm{~min}$. The supernatant was filtered through a $13 \mathrm{~mm}$ diameter and $0.2-\mu \mathrm{m}$ pore-size regenerated cellulose (RC) membrane filter (Whatman, Maidstone, UK) and diluted with water before analysis. High-performance liquid chromatography (HPLC) system (Alliance 2695 system, Waters Corp., Milford, MA) with a Refractive Index Detector 2414 and column BioRad HPX-87H $300 \times 7.8 \mathrm{~mm}$ (Hercules, CA) was used for measuring lactose, glucose, galactose and lactate concentrations.

Analysis of FAA was performed on an ultra-performance liquid chromatography (UPLC) system (Acquity UPLC; Waters Corp.) including a binary solvent manager, a sample manager and photodiode array (PDA) detector, connected to Waters Empower $^{\mathrm{TM}} 2.0$ software. Separations were performed on a $2.1 \times$ $100 \mathrm{~mm}$ Waters Acquity UPLC AccQ•Tag Ultra Column operated at $55^{\circ} \mathrm{C}$, the running time being $12 \mathrm{~min}$. Sample derivatization procedure was as follows: $20 \mu \mathrm{L}$ AccQ•Fluor reagent was added to the mixed solution of $70 \mu \mathrm{L}$ AccQ $\bullet$ Fluor borate buffer and $10 \mu \mathrm{L}$ sample or standard. The mixed solution was vortexed immediately for $10 \mathrm{~s}$, transferred to an autosampler vial and allowed to stand at room temperature for $1 \mathrm{~min}$. Then the vials were placed in a heating block at $55^{\circ} \mathrm{C}$ for $10 \mathrm{~min}$, after which they were analyzed by the UPLC system. Empower software (Waters Corp.) was used for the data processing.

The $\mathrm{pH}$ of milk samples was measured with $\mathrm{pH}$ meter S20 Seven Easy equipped with InLab 413 electrode (Mettler-Toledo $\mathrm{GmbH}$, Greifensee, Switzerland).

\section{CALCULATION OF GROWTH PARAMETERS CHARACTERIZING METABOLISM OF THE GROWING CELLS}

The growth characteristics of the bacteria (yield coefficient values, growth rates etc.) during the growth in milk were calculated on the basis of the heat evolution converted to biomass concentrations or cell numbers and concentrations of organic acids etc. in the culture media as follows:

$$
\mu=\frac{\ln \left(N_{2} / N_{1}\right)}{t_{2}-t_{1}}
$$

$$
\begin{aligned}
& I_{\text {Lactose }}=\frac{d\left(C_{\text {Lactose }}\right)}{d(X)} \\
& O_{\text {Lactose }}=\frac{d\left(C_{\text {Lactose }}\right)}{d(X)} \\
& Y_{\text {Lactate Lactose }}=\frac{d\left(C_{\text {Lactate }}\right)}{d\left(C_{\text {Lactose }}\right)} \\
& Y_{X S}=\frac{d(X)}{\left(d\left(2 \cdot C_{\text {Lactose }}\right)-d\left(C_{G a l}\right)-d(G l c)\right) \times 180 / 1000} \\
& I_{A A}=\frac{d\left(C_{A A}\right)}{d(X)}
\end{aligned}
$$

where $\mu$ is the specific growth rate $\left(\mathrm{h}^{-1}\right), \mathrm{t}$ is time $(\mathrm{h}), N$ is the number of cells calculated assuming that heat produced per cell formation is constant $\left(Y_{Q}=4.45 \times 10^{-9} \mathrm{~J}\right.$ per cell $), X$ is the dry biomass ( $\mathrm{gdw} \mathrm{L}^{-1}$ ), assuming that the mass of one cell is $0.2 \times$ $10^{-12} \mathrm{~g}$ (unpublished data), $\mathrm{I}_{\text {Lactose }}$ is the lactose consumption per biomass produced ( $\mathrm{mmol} \mathrm{gdw}^{-1}$ ), $\mathrm{O}_{\text {Lactate }}$ is the lactate production per biomass produced ( $\left.\mathrm{mmol} \mathrm{gdw}^{-1}\right)$; $\mathrm{C}$ designates the concentration of corresponding compound, for example $C_{\text {Lactate }}$ $(\mathrm{mM}), Y_{\text {Lactate/Lactose }}$ shows the lactate yield per lactose consumed, $Y_{\mathrm{XS}}$ is the biomass yield per hexose consumed and $I_{\mathrm{AA}}$

Table 4 | Mean radii of the colonies of Streptococcus thermophilus ST12 in r-RSM at the "deviation moment," at the end of exponential growth phase and at the end of cultivations at different inoculation rates $10^{6}-10^{1} \mathrm{cfu} \mathrm{mL}^{-1}$.

\begin{tabular}{|c|c|c|c|c|c|c|}
\hline \multirow[t]{2}{*}{$\begin{array}{l}\text { Inoculation } \\
\text { rate, cfu } \mathrm{mL}^{-1}\end{array}$} & \multicolumn{2}{|c|}{$\begin{array}{l}\mathrm{N}^{*} \text { at power-time curves "deviation } \\
\text { moment" }\end{array}$} & \multicolumn{2}{|c|}{$\begin{array}{c}N_{\text {exp }} \text { at the end of exponential } \\
\text { phase }\end{array}$} & \multicolumn{2}{|c|}{$\begin{array}{l}\mathrm{N}_{\text {tot }} \text { at the end of fermentation } \\
\text { (at } 22 \mathrm{~h} \text { ) }\end{array}$} \\
\hline & cfu $\mathrm{mL}^{-1}, \times 10^{7}$ & cfu col-1 & cfu $\mathrm{mL}^{-1}, \times 10^{8}$ & cfu col-1 & cfu $\mathrm{mL}^{-1}, \times 10^{9}$ & cfu col-1 \\
\hline $10^{5}$ & $4.96 \pm 0.24$ & $(4.96 \pm 0.24) \times 10^{2}$ & $5.30 \pm 0.16$ & $(5.30 \pm 0.16) \times 10^{3}$ & $1.56 \pm 0.09$ & $(1.56 \pm 0.09) \times 10^{4}$ \\
\hline $10^{4}$ & $4.81 \pm 0.31$ & $(4.81 \pm 0.31) \times 10^{3}$ & $5.08 \pm 0.44$ & $(5.08 \pm 0.44) \times 10^{4}$ & $1.55 \pm 0.07$ & $(1.55 \pm 0.07) \times 10^{5}$ \\
\hline $10^{3}$ & $4.48 \pm 0.90$ & $(4.48 \pm 0.90) \times 10^{4}$ & $5.13 \pm 0.01$ & $(5.13 \pm 0.01) \times 10^{5}$ & $1.60 \pm 0.01$ & $(1.60 \pm 0.01) \times 10^{6}$ \\
\hline $10^{1}$ & $0.94 \pm 0.08$ & $(0.94 \pm 0.08) \times 10^{5}$ & $3.12 \pm 0.73$ & $(3.12 \pm 0.73) \times 10^{7}$ & $1.45 \pm 0.01$ & $(1.45 \pm 0.01) \times 10^{8}$ \\
\hline
\end{tabular}

\begin{tabular}{lccr}
\hline $\begin{array}{c}\text { Inoculation } \\
\text { rate, cfu } \mathbf{~ m L}^{-1}\end{array}$ & $\begin{array}{c}\text { Rcol at } \\
\text { power-time } \\
\text { curves "deviation } \\
\text { moment," } \boldsymbol{\mu ~} \mathbf{m}\end{array}$ & $\begin{array}{c}\text { Rcol at the } \\
\text { end of } \\
\text { exponential } \\
\text { phase, } \boldsymbol{\mu m}\end{array}$ & $\begin{array}{c}\text { Rcol at the } \\
\text { end of } \\
\text { fermentation } \\
\text { (at 22 h), } \boldsymbol{\mu ~ m}\end{array}$ \\
\hline $10^{6}$ & $2.55 \pm 0.01$ & $5.22 \pm 0.02$ & $7.33 \pm 0.01$ \\
$10^{5}$ & $4.94 \pm 0.33$ & $11.16 \pm 0.11$ & $15.95 \pm 0.31$ \\
$10^{4}$ & $10.14 \pm 0.10$ & $23.69 \pm 0.68$ & $33.85 \pm 0.51$ \\
$10^{3}$ & $22.29 \pm 0.36$ & $51.21 \pm 0.02$ & $73.72 \pm 0.22$ \\
$10^{2}$ & $38.33 \pm 0.92$ & $113.05 \pm 1.69$ & $160.40 \pm 4.13$ \\
$10^{1}$ & $64.68 \pm 3.07$ & $200.73 \pm 15.77$ & $331.12 \pm 1.08$ \\
\hline
\end{tabular}

Radii of average colonies were calculated from average volumes of the colony determined using Kepler's conjecture of bacterial packing of colonies.

Table 3 | The numbers of bacteria in the sample (cfu mL ${ }^{-1}$ ) and in average colonies (cfu col-1) at the "deviation moment," at the end of

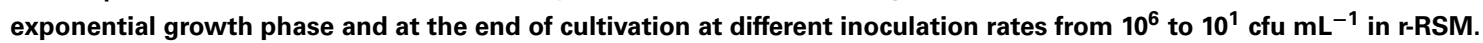

${ }^{*}$ Number of bacteria at the moment of deviation of the microcalorimetric power-time curves obtained in liquid and in renneted reconstituted skim milk samples. 
is the consumption of corresponding amino acid per biomass produced $\left(\mathrm{mmol} \mathrm{gdw}^{-1}\right)$.

\section{STATISTICAL ANALYSIS OF THE DATA}

All the microcalorimetric experiments were repeated twice and measurements were carried out with two or three parallel samples. The power-time curves presented on the Figures and used in the calculations are combined curves of two parallel experiments.

The other analyses (HPLC, UPLC, pH) were carried out in triplicate. All values of the parallel experimental points were averaged and reported along with the value of standard deviation (SD). The experimental data were submitted to single-factor analysis of variance (ANOVA), and the differences of the means were evaluated by Fisher's least significant difference (LSD) test. The difference of the mean values was accepted at the significance level $p<0.05$. The Student's $t$-test was performed to evaluate statistically significant differences between the mean calorimetric values obtained in RSM and r-RSM.

\section{RESULTS}

\section{PECULIARITIES OF THE GROWTH OF ST. THERMOPHILUS ST12 IN} r-RSM

Representative calorimetric power-time curves of the growth of ST 12 in RSM and r-RSM, at inoculation rate $10^{5} \mathrm{CFU} \mathrm{mL}^{-1}$, are presented in Figure 2.

As was previously described (Stulova et al., 2013), a typical microcalorimetric power-time curve of inoculated RSM contained two peaks corresponding to two distinctively separated growth phases (first and second exponential growth phases). As seen in Figure 2, the general pattern with two major exponential growth phases was observed also in r-RSM. The growth curves of St. thermophilus ST12 in r-RSM and RSM were practically coinciding in the beginning, but starting from a certain number of the bacteria in the sample $\left(N^{*}=0.63 \times 10^{7} \mathrm{CFU} \mathrm{mL} \mathrm{mL}^{-1}\right.$ at $N_{0}=10^{5}$ $\left.\mathrm{CFU} \mathrm{mL} \mathrm{m}^{-1}\right)$, at the "deviation moment" marked by the arrow in Figure 2 the maximal calorimetric growth rate $\left(\mu_{\max 1}\right)$ in r-RSM

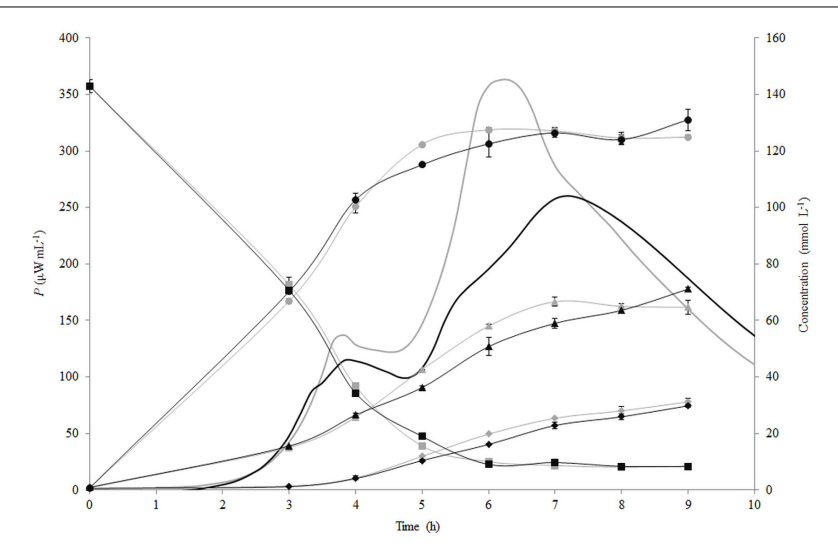

FIGURE 4 | Calorimetric power-time curves (bold line), lactose ( $\square$ ), glucose $(\bullet)$, galactose $(\Delta)$ and lactic acid $(\downarrow)$ profiles during the growth of Streptococcus thermophilus ST12 in liquid (gray) and renneted (black) reconstituted milk. was decreased, branching from the curve of RSM, and the further growth in the coagulated matrix was clearly different from that in RSM. This led to the appearance of the second slower phase in the first exponential phase in comparison with the growth curve in milk (RSM). The splitting of the second exponential growth phase also into two was observed as well-see Figure 2.

As seen in Figure 2, acidification developed more slowly after $3.5 \mathrm{~h}$ of incubation in renneted milk compared to the liquid milk samples which was in a good correlation with the slower growth rate of the bacteria in r-RSM. Higher $\mathrm{pH}$ values in r-RSM samples accompanying the main part of the growth of the bacteria were observed in case of all inoculation rates studied (Figure 3B), in difference from a previous report (Favrot and Maubois, 1996) showing slower acidification in rennet curd only at lower level of

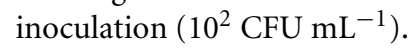

\section{Effect of inoculation rate on power-time curves of St. thermophilus ST12 in r-RSM}

Calorimetric power-time curves of the growth of ST 12 in RSM

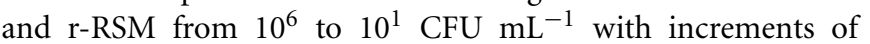
10 -fold, are presented in Figure 3 and processed results were summarized in Table 1. The $t$-test results denoting the differences between liquid and renneted RSM are presented in Table 2.

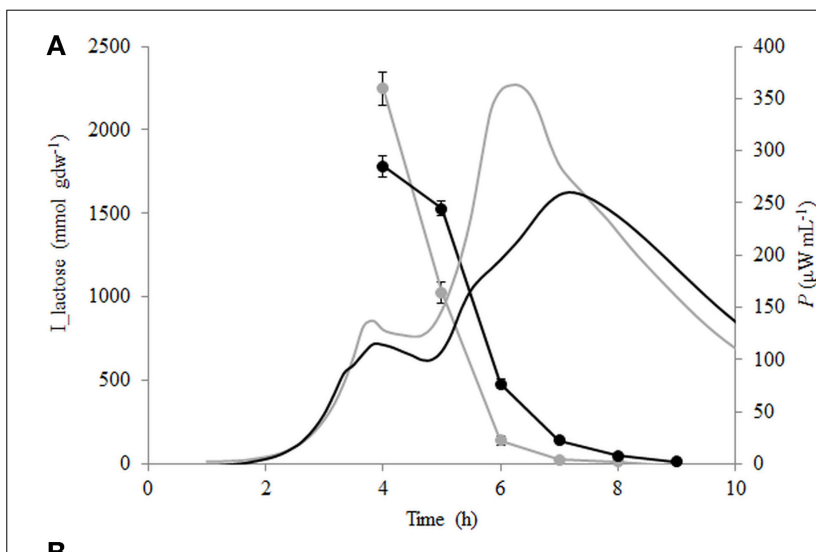

B

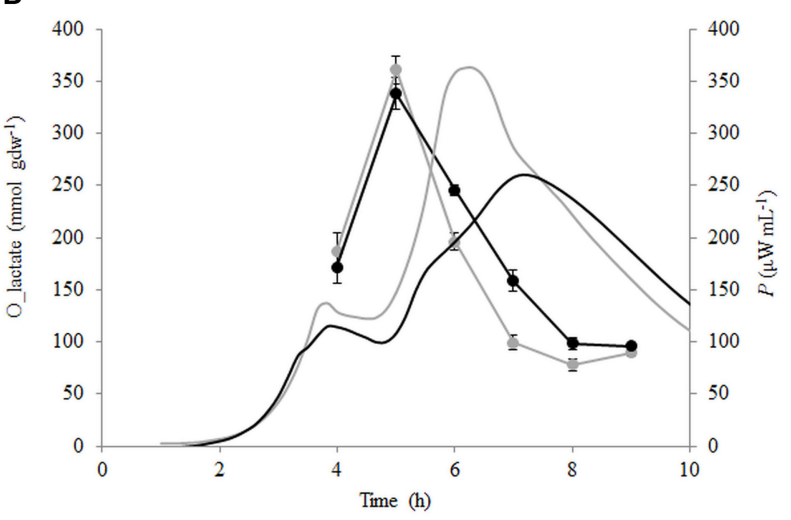

FIGURE 5 | Calorimetric power-time curves (bold line), lactose consumption (A) and lactate production (B) per biomass formed

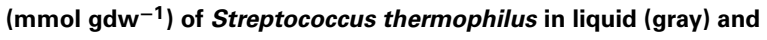
renneted (black) reconstituted milk. 
According to Table 2, the first exponential growth phases of St. thermophilus ST12 in r-RSM were shorter and the calculated $\mu_{\max }$ values were higher than in the second phase like in the case of RSM, however, the noted differences were much more strongly expressed (see also Stulova et al., 2013). As seen from the data presented in Tables 1, 2 the maximal calorimetric growth rates of the first exponential phase $\left(\mu_{\max 1}\right)$ were similar $(P>0.05)$ in RSM and r-RSM at different inoculation rates ranging from $10^{6}$ to $10^{2}$ $\mathrm{CFU} \mathrm{mL} \mathrm{mL}^{-1}$, except $10^{1} \mathrm{CFU} \mathrm{mL}^{-1}$. The values of maximal calorimetric growth rates of the second exponential phase $\left(\mu_{\max 2}\right)$ in r-RSM were significantly lower $(P<0.01)$ than in RSM. This is indicating that the growth of the bacteria in bigger colonies in case of r-RSM is most probably inhibited by the accumulating lactate.

The integrating of the power-time curves allows measure the heat produced by the growing bacteria, where $Q_{\exp }$ indicates the heat produced during the exponential growth phase and $Q_{\text {tot }}$ shows the total heat produced by the total biomass formed during fermentation. According to Table 1 the amounts of heat produced during the exponential phase ( $Q_{\text {exp }}$, average $)$ in r-RSM at inoculation rates ranging $10^{6}-10^{2} \mathrm{CFU} \mathrm{\textrm {mL } ^ { - 1 }}$ were practically the same with average $2.35 \mathrm{~J} \mathrm{~mL}^{-1}$ which corresponds to $5.30 \times 10^{8} \mathrm{CFU}$ $\mathrm{mL}^{-1}$ (calculated using heat yield coefficient $Y_{\mathrm{Q}}$ ). It was about $13 \%$ higher than the same value in $\operatorname{RSM}\left(2.04 \mathrm{~J} \mathrm{~mL}^{-1}\right)$. This fact showed that during the exponential growth phase more bacteria were produced in r-RSM. Noting that the amount of lactate produced during the exponential growth was practically the same in the samples this fact allows to assume that $\mathrm{pH}$ was most probably the factor determining the end of the exponential growth. The amount of heat produced during the total growth $\left(Q_{\text {tot }}\right)$ was the same in r-RSM and RSM at inoculation rates ranging $10^{5}-10^{2}$ $\mathrm{CFU} \mathrm{mL} \mathrm{m}^{-1}-7.14 \pm 0.09 \mathrm{~J} \mathrm{~mL}^{-1}$ that corresponds to the number of bacteria $1.62 \times 10^{9} \mathrm{CFU} \mathrm{mL}^{-1}$. The $Q_{\text {tot }}$ and $N_{\text {tot }}$ values were the lowest in $\mathrm{r}$-RSM at inoculation rate $10^{1} \mathrm{CFU} \mathrm{mL}^{-1}$ $-6.47 \pm 0.06 \mathrm{~J} \mathrm{~mL}^{-1}$ and $1.45 \times 10^{9} \mathrm{CFU} \mathrm{mL} \mathrm{mL}^{-1}$ respectively. This fact showed that growth of the large colonies was clearly inhibited in coagulated milk (but the same amount of bacteria grew without inhibition in RSM).

Clear differences in the $P_{\max }$ values between different inoculation rates in r-RSM are shown in Figure 3. The $P_{\max }$ values were clearly different also if r-RSM and RSM values were compared with each other. As shown in Stulova et al. (2013) the values of $P_{\max }$ were much higher (in average $350 \mu \mathrm{W} \mathrm{mL} \mathrm{m}^{-1}$ ) and very similar at different inoculation rates (see Figure 3 ). The time to reach the maximum heat effect $\left(t_{\mathrm{Pmax}}\right)$ increased with decreasing amounts of inocula (Table 1). As seen from Table 2, there were significant differences noted in $t_{\text {Pmax }}$ between r-RSM and RSM
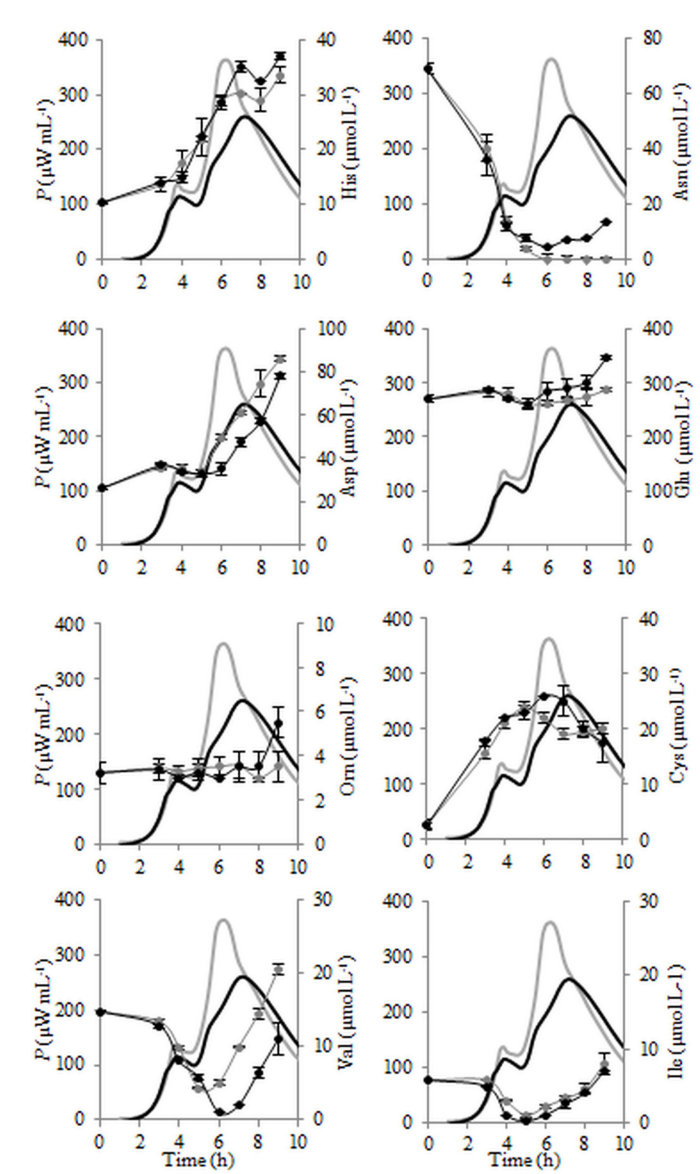
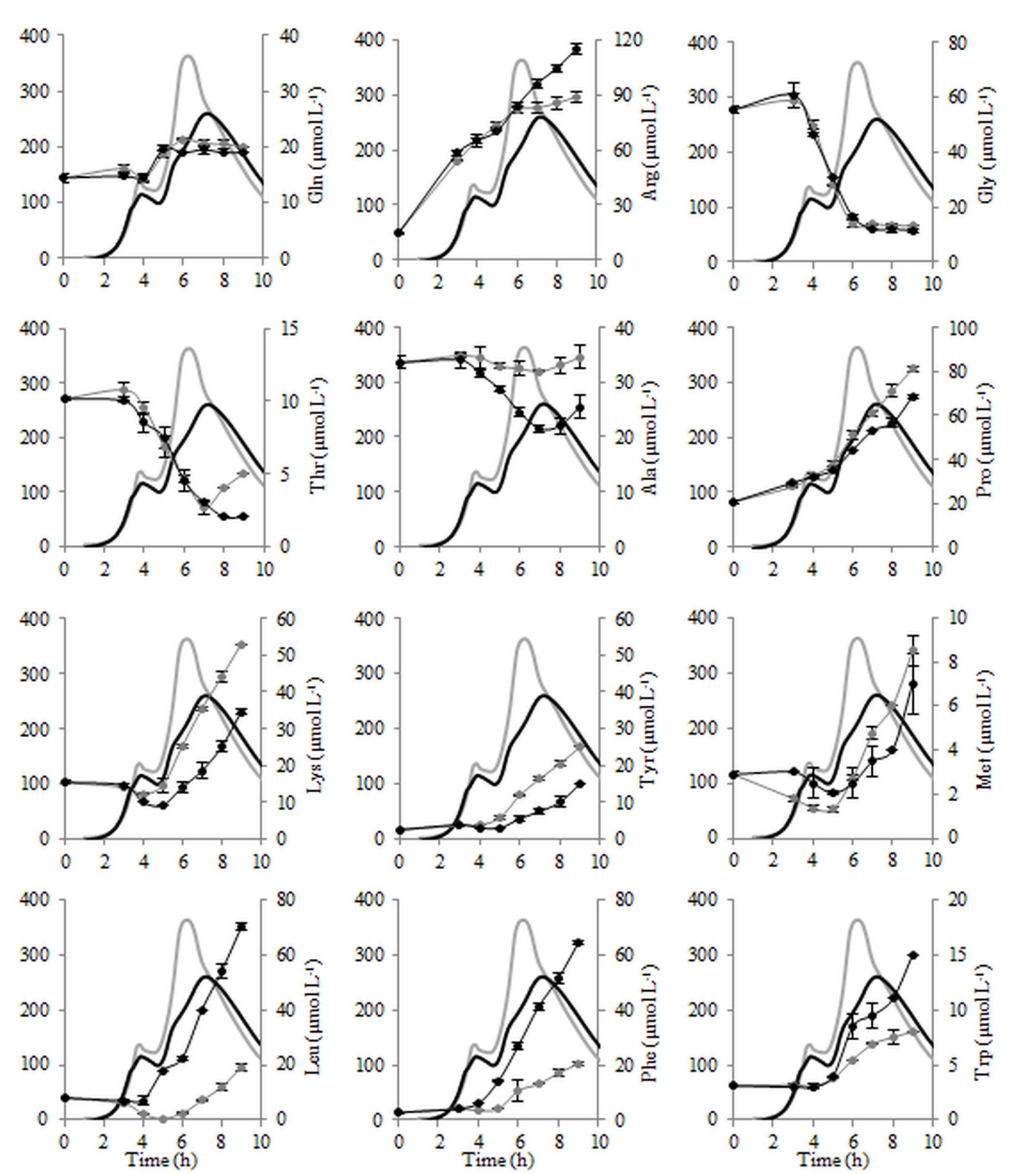

FIGURE 6 | The changes of the concentrations of the individual free amino acids (FAA) during the growth of Streptococcus thermophilus ST12 at inoculation rate $10^{5} \mathrm{CFU} \mathrm{mL} \mathrm{m}^{-1}$ in RSM (gray) and r-RSM (black). 
samples. Depending on the inoculation rate, $1-2.5 \mathrm{~h}$ more time was required to reach the maximum heat production rate $\left(t_{\mathrm{Pmax}}\right)$ in r-RSM compared with RSM (Table 1). These results showed that together with the decrease of the growth rate the length of the exponential phase was increased, which was the expected result.

The most likely explanation for the inhibition of St. thermophilus ST12 growth in r-RSM is that lactate accumulating in the colonies during growth in r-RSM was changing the $\mathrm{pH}$ locally and this led to the inhibiton of growth. The peculiarities of colonial growth of bacteria will be discussed in more detail below (in section Discussion).

Lengths of the lag-phases $(\lambda)$ in r-RSM, as in the case of RSM were changing with regular interval from one inoculation rate to another and became longer on decreasing of the initial inoculum. According to the statistical analysis (Table 2), no big differences were observed in lag-phase $(\lambda)$ durations at the same inoculation rates in both media studied.

\section{Characterization of growth of colonies}

Numbers of bacteria in average colonies in case of different inoculation rates were calculated using the data of the heat evolved during the different phases of the growth and $Y_{\mathrm{Q}}$ value. The radii of the average colonies were calculated using Kepler's conjecture of bacterial packing in colonies (Hsiang, 1993; Hales, 1994). The numbers of bacteria in average colonies (CFU/col) and mean sizes of the average colonies $\left(R_{\mathrm{col}}, \mu \mathrm{m}\right)$ at the "deviation moments," at the end of exponential growth phase and at the end of fermentation at different inoculation rates (from $10^{6}$ to $10^{1} \mathrm{CFU} \mathrm{mL} \mathrm{m}^{-1}$ ) in r-RSM are presented in Tables 3, 4, respectively.

It can be seen from the Table 3 that as expected from the measurements of the heat the total numbers of bacteria in samples at different inoculation rates were practically equal at the end of the cultivations, which automatically means that the grown colonies contained different number of cells. The same was true for the data from the end of the exponential growth.

In agreement with the same type of logic the radii of average colonies at the end of fermentation were varying from $7 \mu \mathrm{m}$ at the highest inoculation rate $10^{6} \mathrm{CFU} \mathrm{mL}^{-1}$ to $331 \mu \mathrm{m}$ at the inoculation rate $10^{1} \mathrm{CFU} \mathrm{mL}^{-1}$ (Table 4). Average size of colonies at inoculation rate $10^{5} \mathrm{CFU} \mathrm{mL} \mathrm{mL}^{-1}$ after $22 \mathrm{~h}$ of fermentation was similar to that measured in a model cheese by Floury et al. (2013)—average diameters of colonies being approximately $30 \mu \mathrm{m}$ and $30-50 \mu \mathrm{m}$, respectively.

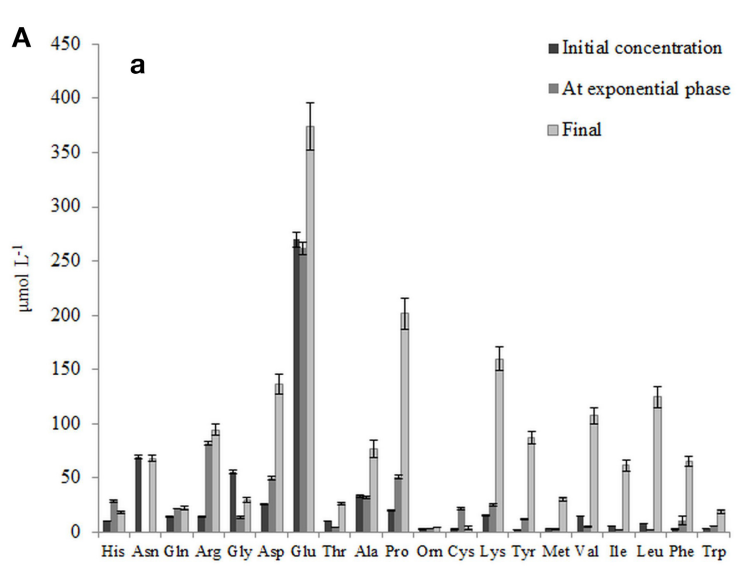

B

a

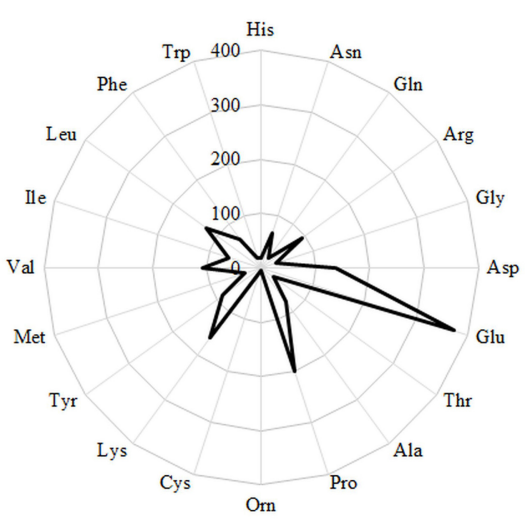

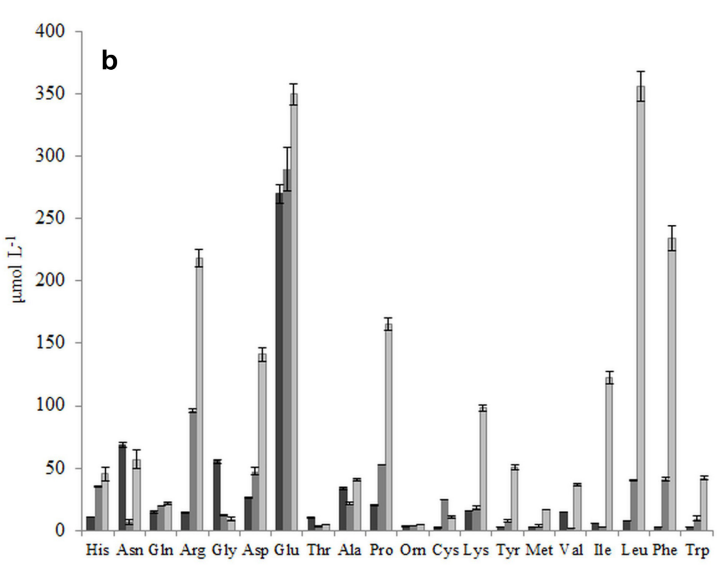

b

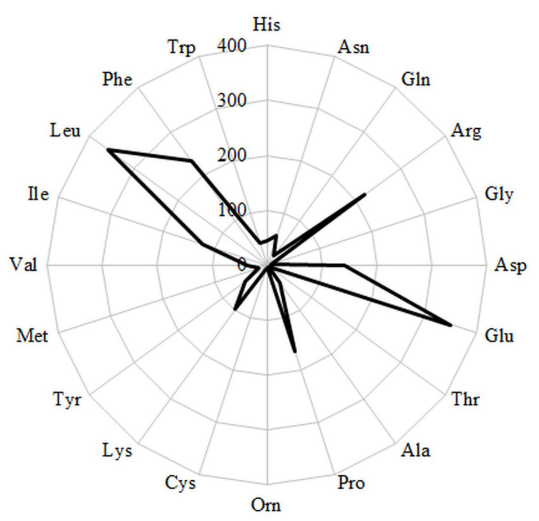

FIGURE 7 | (A) Initial concentrations of free amino acid (FAA) and concentrations of FAA at the end of the exponential phase and at the end of growth in RSM (a) and r-RSM(b). (B) Radar-diagram showing the concentrations of FAA at the end of growth (at $22 \mathrm{~h}$ ) in RSM (a) and r-RSM (b). 
It should be emphasized that only one-third of biomass was synthesized by the end of the second exponential growth phase in r-RSM whereas most of the biomass was synthesized during the post-exponential growth phase (Table 3 ). In contrast to that radii of the colonies at the ends of the second exponential phases reached approximately $70 \%$ of the final values.

If the data obtained showed that the mechanisms determining the end of the exponential phase and end of cultivation in our experiments at $22 \mathrm{~h}$ were not depending on the inoculation rates, then the mechanism leading to the "deviation moment" is more complicated. As seen from the Tables 3, 4 neither the total numbers of bacteria $\mathrm{N}^{*}$ nor the sizes of average colonies were equal at different inoculation rates at the moment when the growth rate of bacteria decreased in the r-RSM in comparison with that in RSM.

\section{UTILIZATION OF CARBOHYDRATES AND PRODUCTION OF LACTIC ACID BY THE BACTERIA IN r-RSM}

The studies of consumption of lactose and formation of organic acids were carried out in the case of inoculation rate of $10^{5} \mathrm{CFU}$ $\mathrm{mL}^{-1}$.

The changes of the concentration of carbohydrates (lactose, glucose, galactose) and lactic acid during fermentation of RSM and r-RSM with St. thermophilus ST12 at inoculation rate $10^{5}$ $\mathrm{CFU} \mathrm{mL} \mathrm{m}^{-1}$ are presented in Figure 4. As seen from this figure, the patterns of hydrolysis of lactose, release of glucose and galactose and formation of lactic acid were practically identical in both RSM and r-RSM (Figure 4). Approximately $130 \mathrm{mmol} \mathrm{L}^{-1}$ of lactose was hydrolysed at the end of the second exponential growth phase (during active growth), $127 \mathrm{mmol} \mathrm{L}^{-1}$ of glucose and $58 \mathrm{mmol} \mathrm{L}^{-1}$ of galactose was utilized by the bacteria, and about $20 \mathrm{mmol} \mathrm{L}^{-1}$ of lactic acid was produced.

Lactose consumption and lactate production per biomass formed $\left(\mathrm{mmol} \mathrm{gdw}^{-1}\right)$ were calculated (see Section Calculation of Growth Parameters Characterizing Metabolism of the Growing Cells) and are presented in Figures 5A,B. During the growth of St. thermophilus ST12, lactose was consumed very fast-up to 2200 and $1800 \mathrm{mmol} \mathrm{gdw}^{-1}$ in liquid and renneted RSM, respectively. Lactose consumption led to the accumulation of galactose, as well as glucose (Figure 5), due to low glycolytic activity of the bacteria, reflected by the low lactate yield per lactose below $0.2 \mathrm{~mol} \mathrm{~mol}^{-1}$ in RSM as well as in r-RSM (theoretical maximum $4 \mathrm{~mol} \mathrm{~mol}^{-1}$ ). It can be assumed that galactose was not metabolized by this strain; however, the accumulation of galactose was lower than predicted compared to the consumption of lactose. This indicated that either galactose was

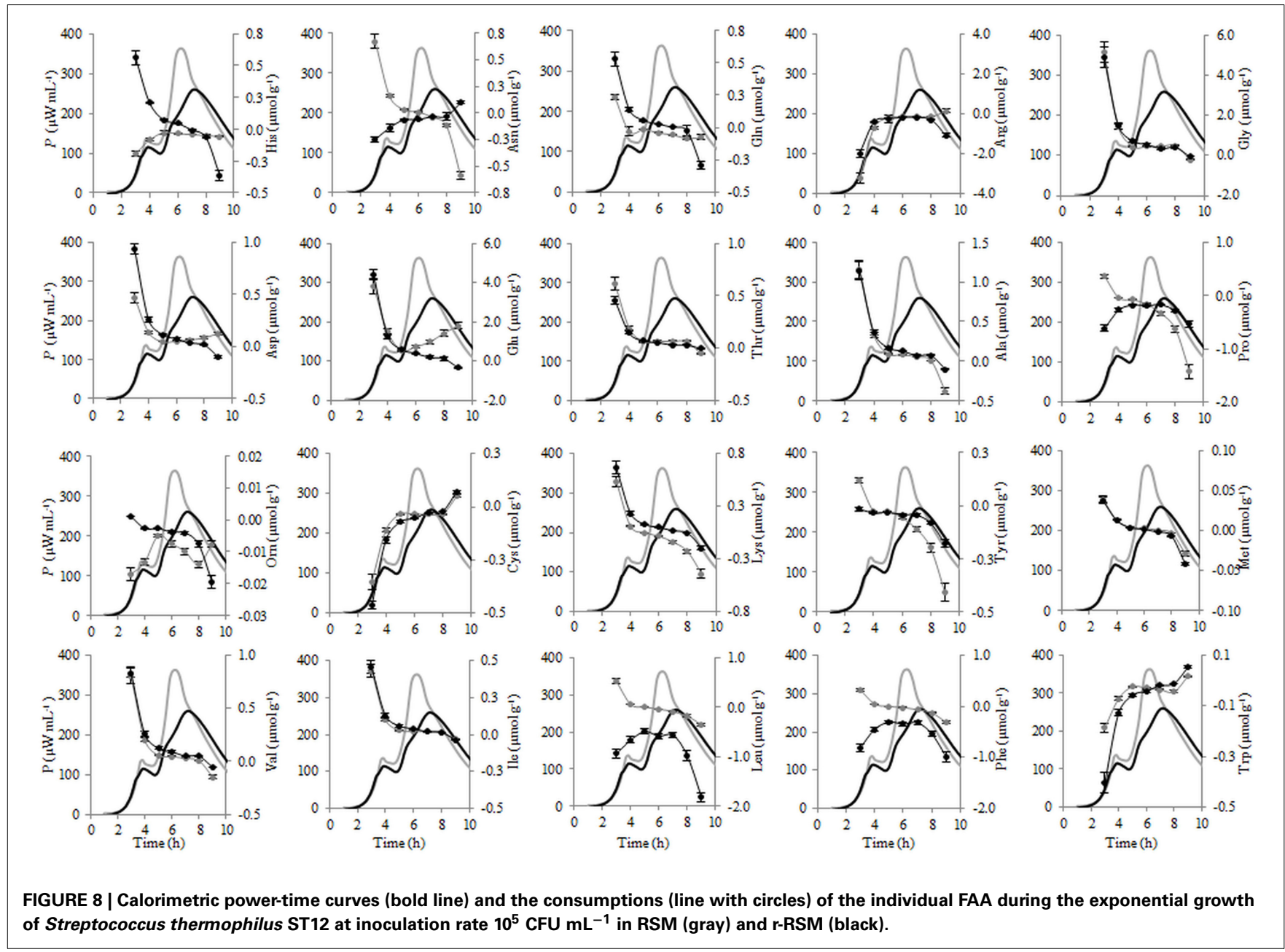


consumed through glycolysis, or it was used for polysaccharide production. Usually polysaccharides are produced in growthrestricted conditions to synthesize carbon storage substances for the future.

\section{CHANGE OF FREE AMINO ACIDS DURING FERMENTATION IN r-RSM}

The changes of the concentrations of the individual FAA during fermentation of liquid and renneted RSM with St. thermophilus ST12 at inoculation $10^{5} \mathrm{CFU} \mathrm{mL}{ }^{-1}$ were evaluated and presented in Figure 6. As seen from Figure 6, glutamic acid was initially the most abundant free amino acid in both, RSM and r-RSM, accounting for $46 \%$ of the total.

There was a dramatic reduction of asparagine, glycine and valine at the end of exponential phase in both RSM and r-RSM. Leucine showed a clear decline in RSM during fermentation, whereas in the case of r-RSM a larger increase of this amino acid as well as phenylalanine was observed. It can be seen from the data presented in Figure 7 that the intensive liberation of the majority of amino acids in RSM and r-RSM was observed during the period from the end of exponential phase till the end of fermentation (from $5 \mathrm{~h}$ till $22 \mathrm{~h}$ ).

The concentrations of the total free amino acids (TFAA) were $15 \%$ higher in r-RSM than those determined in RSM at the end of cultivations, 2024 and $1713 \mu \mathrm{mol} \mathrm{L}^{-1}$, respectively. Glutamic acid, proline, lysine and aspartic acid were the most predominant FAA in RSM at the end of fermentation (at $22 \mathrm{~h}$ ), accounting for $22,12,9$, and $8 \%$ of the total, respectively. In contrast, leucine, glutamic acid, phenylalanine, arginine and proline, accounting for $18,17,12,11$, and $8 \%$ of the total were the dominant amino acids in r-RSM-see Figure 8.

\section{METABOLISM OF AMINO ACIDS AND GROWTH OF THE BACTERIA}

Proteolysis in rennet curd is catalyzed by enzymes from coagulant and enzymes from the inoculated St. thermophilus The initial hydrolysis of caseins is caused by the chymosin which results in the formation of large (water-insoluble) and intermediate-sized (water-soluble) peptides which are degraded subsequently by the coagulant and enzymes from the starters (Sousa et al., 2001). The final products of proteolysis are FAA and their concentration in curd is the net result of the liberation of amino acids from casein, their degradation to catabolic products and also utilization and synthesis by the starter bacteria. Free amino acid concentrations changes were evaluated in liquid and renneted milk samples during the growth of St. thermophilus ST12-see Figures 6-8. Amino acid consumption during the 1 st and 2 nd exponential growth phases is presented in Table 5 Although St. thermophilus has not been shown to be auxotrophic for any single amino acid, growth is abolished when both Glu/Gln and Cys/Met are removed (Letort et al., 2002). In addition, the exhaustion of Leu and Val reduces the growth rate more than three times and only six amino acids (Asn, Ala, Ile, Gly, Ser, and Thr) can be individually omitted without any effect on the growth rate.

Most of the trends in consumption of FAA during the exponential growth of St. thermophilus ST12 in RSM and r-RSM were similar-see Tables 5, 6. The only amino acids consumed in amounts corresponding to the calculated requirements for

Table 5 | Relative consumption of free amino acids (r-I_FAA) compared to that required for the synthesis of biomass proteins (\%).

\begin{tabular}{|c|c|c|c|c|c|c|c|c|c|c|c|c|c|}
\hline \multicolumn{2}{|c|}{ Time of growth, $h$} & 3 & 4 & 5 & 6 & 7 & 8 & 3 & 4 & 5 & 6 & 7 & 8 \\
\hline \multicolumn{2}{|r|}{$\mu$} & 1.71 & 0.90 & 0.59 & 0.77 & 0.46 & 0.24 & 1.68 & 0.88 & 0.47 & 0.47 & 0.52 & 0.43 \\
\hline $\begin{array}{l}\text { r-I_FAA } \\
\text { mmol g }^{-1}\end{array}$ & $\begin{array}{c}\text { Content in } \\
\text { biomass, } \mathrm{mmol} \mathrm{g}^{-1}\end{array}$ & \multicolumn{6}{|c|}{ RSM } & \multicolumn{6}{|c|}{$r-R S M$} \\
\hline r-I_Asn & 0.22 & 2014 & 521 & 305 & 82 & -1 & -9 & 402 & 555 & 231 & 119 & -22 & -24 \\
\hline r-I_GIn & 0.19 & 61 & -23 & -104 & -33 & -4 & 8 & 3 & -36 & -111 & -43 & 2 & 8 \\
\hline r-I_Asp & 0.22 & -249 & -85 & -89 & -125 & -107 & -134 & -38 & 2 & 31 & -65 & -148 & -128 \\
\hline r-I_Glu & 0.19 & -302 & 133 & 375 & 70 & -49 & -108 & 69 & 163 & 13 & -182 & -241 & -205 \\
\hline r-I_Thr & 0.30 & 9 & 27 & 51 & 23 & 6 & -2 & 9 & 33 & 40 & 50 & 19 & 8 \\
\hline r-I_Ala & 0.64 & -11 & 4 & 11 & 4 & 0 & -2 & 5 & 26 & 38 & 42 & 12 & 1 \\
\hline r-I_Pro & 0.18 & -498 & -216 & -241 & -160 & -102 & -121 & -76 & -162 & -200 & -244 & -140 & -85 \\
\hline r-I_Val & 0.36 & 109 & 49 & 64 & 4 & -19 & -32 & 26 & 70 & 79 & 59 & -7 & -19 \\
\hline r-I_Ile & 0.27 & 105 & 36 & 26 & 2 & -8 & -14 & 31 & 53 & 22 & -1 & -19 & -15 \\
\hline r-I_Leu & 0.39 & 122 & 32 & 19 & -7 & -19 & -30 & 1 & -58 & -125 & -155 & -115 & -81 \\
\hline r-I_Phe & 0.18 & -9 & -36 & -69 & -59 & -38 & -43 & -24 & -191 & -335 & -423 & -236 & -144 \\
\hline r-I_Trp & 0.07 & 34 & -29 & -76 & -54 & -31 & -27 & 10 & -93 & -207 & -234 & -99 & -59 \\
\hline
\end{tabular}

Green color shows that free amino acids were consumed more than required for biomass synthesis. Amino acid composition of biomass is taken from the literature (Adamberg et al., 2012). 
Table 6 | Milk composition, maximal amount of biomass that can be obtained from free amino acids (FAA) in milk and relative amount of FAA supporting the synthesis of biomass proteins.

\begin{tabular}{|c|c|c|c|c|c|c|c|c|c|}
\hline Aminoacid & \multicolumn{2}{|c|}{$\begin{array}{l}\text { Composition of } \\
\text { milk }\left(C_{F A A}\right), m M\end{array}$} & Biom. $\left(B_{A A}\right), \mathrm{mmol} \mathrm{g}^{-1}$ a & \multicolumn{2}{|c|}{$\begin{array}{c}\text { Theoretical amount of } \\
\text { biomass from } \\
\text { FAA (Xtheor), } \mathrm{g} \mathrm{L}^{-1} \mathrm{~b}\end{array}$} & \multicolumn{2}{|c|}{$\begin{array}{l}\text { Experimentally determined } \\
\text { biomass (Xexp) at } 8 \mathrm{~h}, \\
\mathrm{~g} \mathrm{~L}^{-1 \mathrm{c}}\end{array}$} & \multicolumn{2}{|c|}{$\begin{array}{l}\text { Max amount of FAA } \\
\text { (r-I_FAA max), \%d }\end{array}$} \\
\hline His & 10.4 & 10.5 & 0.08 & 0.12 & 0.12 & 0.12 & 0.18 & 100 & 70 \\
\hline Asn & 70.1 & 69.9 & 0.22 & 0.33 & 0.32 & 0.12 & 0.18 & 262 & 181 \\
\hline Gly & 55.7 & 56.0 & 0.45 & 0.12 & 0.12 & 0.12 & 0.18 & 99 & 69 \\
\hline Asp & 26.9 & 26.5 & 0.22 & 0.12 & 0.12 & 0.12 & 0.18 & 101 & 69 \\
\hline Glu & 270.0 & 271.0 & 0.19 & 1.46 & 1.46 & 0.12 & 0.18 & 1176 & 817 \\
\hline Thr & 10.2 & 10.1 & 0.3 & 0.03 & 0.03 & 0.12 & 0.18 & 27 & 19 \\
\hline Ala & 33.6 & 33.6 & 0.64 & 0.05 & 0.05 & 0.12 & 0.18 & 42 & 29 \\
\hline Met & 3.0 & 3.0 & 0.07 & 0.04 & 0.04 & 0.12 & 0.18 & 36 & 25 \\
\hline Val & 15.1 & 14.9 & 0.36 & 0.04 & 0.04 & 0.12 & 0.18 & 33 & 23 \\
\hline Ile & 6.0 & 6.0 & 0.27 & 0.02 & 0.02 & 0.12 & 0.18 & 18 & 12 \\
\hline Leu & 8.3 & 8.1 & 0.39 & 0.02 & 0.02 & 0.12 & 0.18 & 17 & 12 \\
\hline Phe & 3.0 & 2.9 & 0.18 & 0.02 & 0.02 & 0.12 & 0.18 & 13 & 9 \\
\hline Trp & 3.2 & 3.3 & 0.07 & 0.04 & 0.05 & 0.12 & 0.18 & 36 & 26 \\
\hline
\end{tabular}

a Biomass composition is taken from literature (Adamberg et al., 2012).

${ }^{b}$ Calculated as $X_{\text {theor }}=\left(C_{A A} / 1000\right) / B_{A A}$ indicating how much biomass can be produced from free amino a acid present in milk assuming that amino acid is used only for the synthesis of biomass proteins. AA refers to corresponding amino acid.

${ }^{c}$ Experimentally determined biomass concentration assuming that heat produced per cell is $4.45 \times 10^{-9} \mathrm{~J}$ per cell and cell mass is $0.2 \times 10^{-12} \mathrm{~g}$.

${ }^{d}$ Calculated as FI_FAA max $=X_{\text {theor }} \times 100 / X_{\text {exp }}$ indicating relative amount of amino acid in biomass proteins that can be supported by consumed free amino acids. Percentage below indicates that free amino acid was less consumed than required for synthesis of biomass proteins.

biomass synthesis in the 1st exponential phase were Gly, Glx $(\mathrm{Gln}+\mathrm{Glu})$ and Asx. These amino acids were also the only amino acids whose concentrations in milk exceeded the amount required for biomass synthesis (Table 6). The amount of free His was also sufficient to satisfy biomass requirements, but it should be noted that the amount of this amino acid did not decrease during the exponential growth of the bacteria. Most of the concentrations of other FAA could not support the growth of cells more than 30\%. Free Arg and Pro in milk could support amino acid requirements for over $40 \%$ but instead of decrease the concentrations of these amino acids increased during the 1st exponential growth phase. This pattern was quite general. Accumulation of amino acids in the media, especially in renneted milk samples due to their release from proteins, and most noticeably during the second exponential growth phase, made it impossible to analyse consumptions of amino acids in this growth phase.

Overconsumption of Glu 5-7 times exceeding the need for biomass synthesis indicated the potential of the synthesis of other amino acids from it. In total, $4.6 \mathrm{mmol} \mathrm{g} \mathrm{g}^{-1}$ of amino acids were incorporated into the biomass. Of the total, $30 \%$ was covered by the consumption of FAA (excluding Glu). If we take into account Glu overconsumption and amino group transfer to other amino acids, Glu can provide ammonia for $25 \%$ of amino acids of the biomass. The remaining $45 \%$ of amino acids must be have been derived from peptides.

\section{DISCUSSION}

During the last years, there has been a significant increase of interest in study of growth of bacterial colonies in dairy food matrices (especially in cheese matrices). It has been shown that location, distribution of the cells in different zones of the matrices as well as size of the colonies and distances between colonies are important factors determining peculiarities of cheese ripening processes, influencing utilization of the nutrients and diffusion of metabolites within the cheese matrices (Ercolini et al., 2003; Jeanson et al., 2011; Floury et al., 2013). However, the first systematic comparative study of quantitative peculiarities of growth and metabolism of a LAB St. thermophilus ST12 at different inoculation rates in liquid and renneted milk during the whole growth of the bacteria was carried out in this paper to our knowledge. A novel non-invasive method of microcalorimetry developed by us was used throughout the study. The method developed and used allowed obtain the first time quantitative data on the growth kinetics of colonies of different sizes in renneted milk.

It was shown that the growth patterns of St. thermophilus ST12 in r-RSM during fermentation at $40^{\circ} \mathrm{C}$ were clearly multiphase 
in comparison with diauxic growth of St. thermophilus ST12 in RSM. Decrease of the maximal calorimetric growth rates $\mu_{\max }$ during the first and the second exponential growth phases as well as remarkably lower values of maximum heat flows $P_{\max }$ $\left(\mathrm{W} \mathrm{mL} \mathrm{m}^{-1}\right.$ ) of the thermophilic starters growing in r-RSM were observed. The noted inhibition of growth rates in the r-RSM could be explained most probably by the accumulation of lactate in the colonies leading to the change of $\mathrm{pH}$. This conclusion was supported also by the fact that lactate inhibition was not observed in RSM where the buffering capacity of liquid milk was sufficient for alleviating of the influence of lactate (see Figure 3 ).

The data obtained showed that the numbers of bacteria in the end of the exponential phase (combined exponential phase, see above), as well as in the end of the cultivations were practically the same at different inoculation rates, see Table 3. This allowed introduce a very simple calculation scheme for the determination of the sizes of the colonies, including the radii, in these important points at different inoculation rates presented in Table 3. However, the total numbers of bacteria in the end of the exponential growth in r-RSM were higher than in RSM for about $13 \%$ at all except at low inoculation rates. This fact could be explained by the lower rate of decrease of $\mathrm{pH}$ in the r-RSM in comparison with RSM indicating that buffering capacity of the matrices is important in determining the end of the exponential growth of the bacteria in milk, not accumulation of lactate directly.

It should be noted that the total numbers of bacteria in the "deviation points" were not the same at different inoculation rates as expected from the data presented above. This was indicating that these points were determined not by a "uniform" mechanism like the end of exponential growth phases and the end of growth during the cultivation but in this case most probably also the sizes of colonies were playing more important role in determining the local buffering capacity in the colonies. Another factor derived from the size of colonies is the availability of nutrients (essential amino acids) for bacteria as proteases are cell bound and cannot freely move in the environment to deliberate peptides from casein.

An observation showing that the growth rates of bacteria in small colonies in the beginning of the cultivation at all inoculation rates were the same as in liquid milk indicated that diffusion rate of glucose was practically the same in these two types of samples.

\section{CONCLUSIONS}

The present study clearly showed potential of non-invasive method of microcalorimetry in combination with the other analytical methods in study of quantitative peculiarities of growth and metabolism of bacteria in opaque and solid state media-see a detailed comparison of the methods in Lobete et al. (in press). It was possible to elucidate the quantitatively characterized growth patterns of Streptococcus thermophilus ST12 in renneted milk at different inoculation rates and compare them with the patterns of growth of the bacteria in milk. Clear discriminative results of growth and metabolic patterns of cells in renneted and liquid milk encourage use of microcalorimetry more widely as a screening tool for strain selection in their natural environment (milk or curd).

\section{ACKNOWLEDGMENTS}

The financial support for this research was financially supported through the grant ETF7636 of Estonian Science Foundation, through the institutional research funding (IUT 1927) of Estonian Ministry of Education and Research, and by the EU Regional Development Fund projects EU28912, EU29994 and 3.2.0701.110018.

\section{REFERENCES}

Adamberg, K., Seiman, A., and Vilu, R. (2012). Increased biomass yield of Lactococcus lactis by reduced overconsumption of amino acids and increased catalytic activities of enzymes. PLOS ONE 7:e48223. doi: 10.1371/journal.pone.0048223

Berridge, N. J., Cousins, C. M., and Cliffe, A. J. (1974). Microcalorimetry applied to certain species of bacteria growing in sterilized separated milk. J. Dairy Res. 41, 203-215. doi: 10.1017/S0022029900019622

Brocklehurst, T. F., Mitchell, G. A., Ridge, Y. P., Seale, R., and Smith, A. C. (1995). The effect of transient temperatures on the growth of Salmonella typhimurium LT2 in gelatin gel. Int. J. Food Microbiol. 27, 45-60. doi: 10.1016/01681605(94)00152-V

Ercolini, D., Hill, P. J., Dodd, C. E. R. (2003). Bacterial community structure and location in Stilton cheese. Appl. Environ. Microbiol. 69, 3540-3548. doi: 10.1016/j.ijfoodmicro.2006.09.003

Favrot, C., and Maubois, J. L. (1994). Growth of Lactococcus lactis subsp lactis in reconstituted irradiated milk powder. Lait 74, 253-266. doi: 10.1051/lait:1994421

Favrot, C., and Maubois, J. L. (1996). Growth of Lactococcus lactis in milk and rennet curd: influence of the level of inoculation. Lait 76, 193-208. doi: 10.1051/lait:1996317

Floury, J., Jeanson, S., Aly, S., and Lortal, S. (2010). Determination of the diffusion coefficients of small solutes in cheese: a review. Dairy Sci. Technol. 90, 477-508. doi: $10.1051 / \mathrm{dst} / 2010011$

Floury, J., Jeanson, S., Madec, M.-N., and Lortal, S. (2013). Porosity of Lactococcus lactis subsp. lactis LD61 colonies in model cheese. Int. J. Food Microbiol. 163, 64-70. doi: 10.1016/j.ijfoodmicro.2013.02.014

Fujita, T., Monk, P. R., and Wadsö, I. (1978). Calorimetric identification of several strains of lactic acid bacteria. J. Dairy Res. 45, 457-463.

Gardea, A. A., Carvajal-Millán, E., Higuera-Ciapara, I., Figueroa, C., MolinaCorral, J., Rascón, A., et al. (2002). Calorimetric assessment of microbial growth in milk as affected by different conditions. Thermochim. Acta 394, 179-184. doi: 10.1016/S0040-6031(02)00248-4

Hales, T. C. (1994). The status of the Kepler conjecture. Math. Intell. 16, 47-58.

Hsiang, W.-I. (1993). On the sphere packing problem and the proof of Kepler's conjecture. Int. J. Math. 4, 739-831.

Jeanson, S., Chadœuf, J., Madec, M. N., Aly, S., Floury, J., Brocklehurst, T. F., et al. (2011). Spatial distribution of bacterial colonies in a model cheese. Appl. Environ. Microbiol. 77, 1493-1500. doi: 10.1128/AEM.02233-10

Kabanova, N., Kazarjan, A., Stulova, I., and Vilu, R. (2009). Microcalorimetric study of growth of Lactococcus lactis IL1403 at different glucose concentrations in broth. Thermochim. Acta 496, 87-92. doi: 10.1016/j.tca.2009.07.003

Kabanova, N., Stulova, I., and Vilu, R. (2012). Microcalorimetric study of the growth of bacterial colonies of Lactococcus lactis IL1403 in agar gels. Food Microbiol. 29, 67-79. doi: 10.1016/j.fm.2011.08.018

Kriščiunaite, T., Stulova, I., Kabanova, N., Laht, T.-M., and Vilu, R. (2011). The effect of hydrogen peroxide on the growth of thermophilic lactic starter and acid gelation of UHT milk. Int. Dairy J. 21, 239-246. doi: 10.1016/j.idairyj.2010.11.012

Letort, C., Nardi, M., Garault, P., Monnet, V., and Juillard, V. (2002). Casein utilization by Streptococcus thermophilus results in a diauxic growth in milk. Appl. Environ. Microbiol. 68, 3162-3165. doi: 10.1128/AEM.68.6.31623165.2002

Lobete, M. M., Fernandes, E. N., and Van Impe, J. F. M. (in press). Recent trends in non-invasive in situ techniques to monitor bacterial colonies in solid (model) food. Front. Microbiol.

Malakar, P. K., Martens, D. E., van Breukelen, W., Boom, R. M., Zwietering, M. H., and van't Riet, K. (2002). Modeling the interactions of Lactobacillus curvatus colonies in solid medium: consequences for food quality and 
safety. Appl. Environ. Microbiol. 68, 3432-3441. doi: 10.1128/AEM.68.7.34323441.2002

Maskow, T., and Babel, W. (2003). Thermokinetic description of anaerobic growth of Halomonas halodenitrificans using a static microcalorimetric ampoule technique. J. Biotech. 101, 267-274. doi: 10.1016/S0168-1656(02) 00341-3

McKay, A. L., Peters, A. C., and Wimpenny, J. W. T. (1997). Determining specific growth rates in different regions of Salmonella typhimurium colonies. Lett. Appl. Microbiol. 24, 74-76. doi: 10.1046/j.1472-765X.1997.00354.x

Monk, P. R. (1979). Thermograms of Streptococcus thermophilus and Lactobacillus bulgaricus in single and mixed culture in milk medium. J. Dairy Res. 46, 485-496. doi: 10.1017/S0022029900017519

Riva, M., Franzetti, L., Galli, A., and Schiraldi, A. (1997). Growth and fermentation activity of Streptococcus thermophilus and Lactobacillus delbrueckii subsp. bulgaricus in milk: a calorimetric investigation. Ann. Microbiol. Enzimol. 47, 199-211.

Sousa, M. J., Ardö, Y., and McSweeny, P. L. H. (2001). Advances in the study of proteolysis during cheese ripening. Int. Dairy J. 11, 327-345. doi: 10.1016/S09586946(01)00062-0

Stulova, I., Kabanova, N., Kriščiunaite, T., Laht, T.-M., and Vilu, R. (2011). The effect of milk heat treatment on the growth characteristics of lactic acid bacteria. Agron. Res. 9, 473-478.

Stulova, I., Kabanova, N., Kriščiunaite, T., Taivosalo, A., Laht, T.-M., and Vilu, R. (2013). Fermentation of reconstituted milk by Streptococcus thermophilus: effect of irradiation on skim milk powder. Int. Dairy J. 31, 139-149. doi: 10.1016/j.idairyj.2013.02.004

Velliou, E. G., Noriega, E., Van Derlinden, E., Mertens, L., Boons, K., Geeraerd, A. H., et al. (2013). The effect of colony formation on the heat inactivation dynamics of Escherichia coli K12 and Samonella typhimurium. Food Res. Int. 54, 1746-1752. doi: 10.1016/j.foodres.2013.09.009

Wadsö, L., and Galindo, F. G. (2009). Isothermal calorimetry for biological applications in food science and technology. Food Control 20, 956-961. doi: 10.1016/j.foodcont.2008.11.008

Wilson, P. D. G., Brocklehurst, T. F., Arino, S., Thuault, D., Jakobsen, M., Lange, M., et al. (2002). Modelling microbial growth in structured foods: towards a unified approach. Int. J. Food Microbiol. 73, 275-289. doi: 10.1016/S01681605(01)00660-2

Conflict of Interest Statement: The authors declare that the research was conducted in the absence of any commercial or financial relationships that could be construed as a potential conflict of interest.

Received: 06 October 2014; accepted: 22 January 2015; published online: 10 February 2015.

Citation: Stulova I, Kabanova N, Kriščiunaite T, Adamberg K, Laht T-M and Vilu $R$ (2015) Microcalorimetric study of the growth of Streptococcus thermophilus in renneted milk. Front. Microbiol. 6:79. doi: 10.3389/fmicb.2015.00079

This article was submitted to Food Microbiology, a section of the journal Frontiers in Microbiology.

Copyright () 2015 Stulova, Kabanova, Krǐ̌čiunaite, Adamberg, Laht and Vilu. This is an open-access article distributed under the terms of the Creative Commons Attribution License (CC BY). The use, distribution or reproduction in other forums is permitted, provided the original author(s) or licensor are credited and that the original publication in this journal is cited, in accordance with accepted academic practice. No use, distribution or reproduction is permitted which does not comply with these terms. 